\title{
Oestrogen and progesterone receptors in the marmoset endometrium: changes during the ovulatory cycle, early pregnancy and after inhibition of vascular endothelial growth factor, GnRH or ovariectomy
}

\author{
Audrey Silvestri and Hamish M Fraser \\ Medical Research Council Human Reproductive Sciences Unit, The Queen's Medical Research Institute, \\ 47 Little France Crescent, Edinburgh EH16 4TJ, UK
}

Correspondence should be addressed to H M Fraser; Email: h.fraser@hrsu.mrc.ac.uk

\begin{abstract}
Marmosets are widely used, but detailed studies on localisation of endometrial oestrogen receptors $\alpha$ and $\beta$ (ER $\alpha$ and ER $\beta$ ), and the progesterone receptor (PR) are lacking. These receptors were localised and semi-quantitatively analysed throughout the ovulatory cycle, weeks 2, 3 and 4 of pregnancy and after treatment with $\mathrm{GnRH}$ antagonist, vascular endothelial growth factor (VEGF) Trap or ovariectomy. The PR in epithelial cells increased markedly between the mid- and late proliferative phases before declining in the mid-secretory phase and pregnancy. PR in stromal cells was present throughout the cycle and levels were maintained in pregnancy. ER $\alpha$ was present at the mid-proliferative phase and increased in glands at the late proliferative and early secretory phases, before declining at the late secretory phase and week 4 of pregnancy. Stromal ER $\alpha$ showed a similar trend, but decreased earlier, by the mid-secretory phase. ER $\beta$ was highly expressed in epithelial cells throughout the cycle and in pregnancy. In stroma, increases in ER $\beta$ expression were observed at the late proliferative phase with the staining index decreasing by half as the secretory phase progressed and in pregnancy. GnRH antagonist, VEGF Trap or ovariectomy caused significant reductions in PR and ERß expression, but not in ER $\alpha$ when compared with the late proliferative phase of the normal cycle. Endothelial cells expressed ERß, but not ER $\alpha$ or PR. It is concluded that the steroid receptor profile in the marmoset endometrium is generally similar to the human and should provide a useful model for studies on hormonal manipulation of the endometrium.

Reproduction (2007) 134 341-353
\end{abstract}

\section{Introduction}

Cellular proliferation and function in the endometrium, including cyclical menstruation and establishment of pregnancy, are regulated by steroid hormones, in particular oestrogen and progesterone. Disorders of the endometrium constitute a major health problem and manipulation of endometrial steroid receptors are involved in development of novel therapies (Jabbour et al. 2006). Insights into the regulation of steroid receptors in women have been obtained following treatment in vivo, using receptor antagonists such as mifepristone (Critchley et al. 2003, Milne et al. 2005), but such studies are constrained and the investigation of normal uterine physiology and the response to novel agents that affect it requires the use of animal models. The principal experimental non-human primates for studies of hormone action in the endometrium have been macaques (Brenner \& Slayden 1994, 2004) and baboons (Albrecht \& Pepe 2003), but their use is restricted and alternative species are being sought (Carroll et al. 2007). The common marmoset (Callithrix jacchus) is widely used in reproductive research (Fraser \& Lunn 1999, Abbott et al. 2003, Einspanier et al. 2006b). Its advantages are that it breeds throughout the year with high fecundity so that there are many self-sustaining colonies. Housing is relatively easy and economical because of its small size, which also makes it efficient for studying effects of valuable compounds with limited availability.

The marmoset uterus is of the simplex type as in the human. However, it cannot be assumed that the regulation of the uterus in this non-menstruating New World primate will be similar to the human, or the macaques (Old World primates) for that matter (Abbott et al. 2003). While the length of the ovulatory cycle is similar, the follicular phase is shorter at 8 days and the luteal phase is correspondingly longer being in the region of 20 days. Implantation takes place 11 days after ovulation, as opposed to days 7 and 8 in humans and 
macaques (Enders 2000, Niklaus et al. 2001) and depth of implantation is superficial (Niklaus et al. 2001, Wulff et al. 2003). Furthermore, levels of total and free plasma steroids, including oestradiol and progesterone, are exceptionally high (Harlow et al. 1983, Smith \& Fraser 1991). This is a result of end organ resistance mediated by two factors. First, overexpression and higher affinity of an intracellular cytosolic-binding protein, the immunophilin FK-binding protein 51, that specifically impairs binding to receptors and contributes to steroid hormone resistance, at least to glucocorticoid and progesterone (Hubler et al. 2003, Westberry et al. 2006). In addition, the steroid receptors are of low binding affinity (Westberry et al. 2006). In early pregnancy, the corpus luteum secretes plasma progesterone at levels similar to the mid-luteal phase, rather than rising further as in macaques and humans (Smith \& Fraser 1991, Rowe et al. 2002).

The aim of the current study was to establish the localisation and changes in oestrogen receptors $\alpha$ and $\beta 1$ $(E R \alpha$ and $E R \beta)$ and the progesterone receptor (PR) during the normal cycle, the implantation period, early pregnancy and after hormone manipulation in vivo. Antibodies that specifically identify these receptors in the marmoset reproductive tract have been identified and characterised (Saunders et al. 2000, McKinnell et al. 2001, Sierens et al. 2004). Although some information on the localisation of these receptors in marmoset endometrium has been reported, these observations have been limited to a small number of animals (Niklaus et al. 2001, Sierens et al. 2004) and disagree with earlier results (Kholkute et al. 2000), suggesting an absence of expression in epithelial cells. The detailed evaluations in the current study was made possible as a result of collecting tissue from experiments primarily aimed at elucidating the changes in angiogenesis occurring in the ovary during the normal cycle (Dickson \& Fraser 2000), early pregnancy (Rowe et al. 2002) and after inhibiting gonadotrophin releasing hormone $(\mathrm{GnRH}$; Taylor et al. 2004) or vascular endothelial growth factor (VEGF; Wulff et al. 2001, 2002). To compare these treatments, which suppress plasma oestradiol and prevent the ovulatory rise in progesterone, with the complete removal of ovarian steroids, marmosets were ovariectomised at the same stage of the cycle as the GnRH and VEGF antagonist treatments were initiated.

\section{Material and Methods}

\section{Animals and treatments}

The studies were approved by the local Primate Ethical Committee and carried out under Project Licences PPL 60/2472 and PPL 60/3250 granted by the UK Home Office. Adult female marmosets ( $C$. jacchus), weighing between 350 and $450 \mathrm{~g}$, were housed with a younger sister or pre-pubertal female. Ovulation was determined by measuring plasma progesterone profiles in samples collected on Monday, Wednesday and Friday. Plasma progesterone levels are $<32 \mathrm{nmol} / /$ during the follicular phase in the marmoset. Ovulation, designated luteal day 0 , was defined as the day preceding a rise in progesterone concentrations above $32 \mathrm{nmol} / \mathrm{l}$ followed by a progressive increase in progesterone (Harlow et al. 1983, 1984, Gilchrist et al. 2001). There is some variation in the length of the luteal phase in the marmoset and together with the relatively short follicular phase it makes if difficult to collect tissue to constitute an early proliferative phase group. It was decided therefore, to synchronise the proliferative phase by inducing luteolysis beginning on days $14-16$ post-ovulation. This method of synchronising follicular recruitment is followed by follicle selection on cycle day 5 and ovulation around day 10 (Summers et al. 1985, Gilchrist et al. 2001), periods which were classified as mid- and late proliferative phases respectively. To synchronise the timing of the proliferative phase, marmosets were injected with $1 \mu \mathrm{g}$ prostaglandin $\mathrm{F}_{2 \alpha}$ analogue (cloprostenol, Planate, Coopers Animal Health Ltd, Crewe, UK), intramuscularly to induce luteolysis (Summers et al. 1985, Gilchrist et al. 2001). Secretory phase tissue was collected either from animals that had been synchronised with prostaglandin or from spontaneous cycles over the periods, early secretory (days 2-4 postovulation), mid-secretory (days 12-14 post-ovulation) or late secretory phase (days 19-21 post-ovulation). To study changes during very early pregnancy, marmosets were treated with prostaglandin analogue as described above and a fertile male introduced. The stage of pregnancy was calculated taking day 0 as estimated day of ovulation. Uteri were collected at weeks 2, 3 and 4 of pregnancy where the presence of a trophoblast had been confirmed by serial sections as published before (Rowe et al. 2002, 2003).

A second experiment addressed the effects of ovariectomy or inhibiting GnRH or VEGF throughout the proliferative phase. Marmosets were treated with a $\mathrm{GnRH}$ antagonist or VEGF Trap starting between luteal days 14-16 (Wulff et al. 2002, Taylor et al. 2004, 2006). To block the action of VEGF, we employed the VEGF Trap, a recombinant chimeric protein comprising portions of the extracellular domains of the human VEGF receptors VEGFR1 and VEGFR2 expressed in sequence with the Fc portion of human immunoglobulin (Holash et al. 2002). The VEGF Trap binds all isoforms of VEGF-A, and placental growth factor, but does not bind VEGF B or C. VEGF Trap was administered as a single injection of $25 \mathrm{mg} / \mathrm{kg}$ s.c. To block the $\mathrm{GnRH}$ receptor, the GnRH antagonist, Teverelix, [N-Ac-D-Nal ${ }^{1}, \mathrm{D}-\mathrm{pCl}-$ $\left.\mathrm{Phe}^{2}, \mathrm{D}-\mathrm{Pal}{ }^{3}, \mathrm{D}-(\mathrm{Hci})^{6}, \mathrm{Lys}(\mathrm{iPr})^{8}, \mathrm{D}-\mathrm{Ala}{ }^{10}\right] \mathrm{GnRH}$ (Europeptides, Argenteuil, France) dissolved in water to a concentration of $10 \mathrm{mg} / \mathrm{ml}$ was used. To provide a slow-release depot Teverelix was administered at a single dose of $12 \mathrm{mg} / \mathrm{kg}$, injected subcutaneously (Taylor 
et al. 2004). In addition, to determine the effects of total withdrawal of ovarian steroids, four marmosets were ovariectomised following sedation with ketamine hydrochloride (Parke-Davis Veterinary, Pontypool, Gwent, UK), anaesthesia by Saffan (Alphaxalone/Alpadalone, Schering-Plough Animal Health, Welwyn Garden City, UK) and maintenance of analgesia by buprenorphine (Alstoe Animal Health, Melton Mowbray, UK) i.m. Ovariectomy was carried out between days 14 and 16 of the luteal phase, and uteri collected 10 days later; the same schedule as for the VEGF Trap and GnRH antagonist treatments. These treatments were continued for 10 days and results from these groups were compared with the late proliferative phase which corresponds to 10 days post-luteolysis. Five animals were studied for each group throughout the cycle and pregnancy and four for each treatment group.

At the allotted stage, animals were sedated using $100 \mu \mathrm{l}$ ketamine hydrochloride (Parke-Davis Veterinary) and killed with an i.v. injection of $400 \mu$ l Euthetal (sodium pentobarbitone, Rhone Merieux, Harlow, Essex, UK). After cardiac exsanguination, the uterus was removed immediately, weighed and fixed in $4 \%$ neutral buffered formalin for $24 \mathrm{~h}$ before being transferred into $70 \%$ ethanol, dehydrated and embedded in paraffin according to standard procedures. The uteri were placed sagitally, serially sectioned and tissue sections $(5 \mu \mathrm{m})$ placed onto superfrost slides (Merck Poole, Dorset, UK). Sections were cut so that most of the fundal region of the uterus was observed. Whole uterine sections, in duplicate, were mounted on the microscope slides. All specimens included in the study met the stage of the cycle confirmed by ovarian morphology.

\section{Immunocytochemistry}

Paraffin wax was removed by immersion in Xylene (Fisher Scientific UK Ltd, Loughborough, Leicestershire, UK). The sections were rehydrated by a decreasing concentration of ethanol and washed in tap water. To localise PR, antigen retrieval was performed by boiling sections in $0.01 \mathrm{M}$ citrate buffer, $\mathrm{pH} 6$, for $5 \mathrm{~min}$ at high pressure setting 2 in a Tefal Clypso pressure cooker (Tefal, Essex, UK). Slides were then left for 20 min in hot buffer and washed in water. The endogenous peroxidase activity was blocked by immersing all sections in 3\% $(\mathrm{v} / \mathrm{v}) \mathrm{H}_{2} \mathrm{O}_{2}$ in methanol (both from BDH Laboratory Supplies, Poole, UK) for 30 min followed by two 5-min washes in Tris-buffered saline (TBS; $0.05 \mathrm{~mol} / \mathrm{l}$ Tris $(\mathrm{pH}$ 7.4), $\mathrm{NaCl} 9 \mathrm{~g} / \mathrm{l})$. To prevent non-specific binding of the biotinylated second antibody, sections were blocked with normal porcine serum (NPS; Diagnostic Services, Carluke, UK) diluted in a ratio of 1:5 in TBS containing $5 \%(\mathrm{w} / \mathrm{v}$ ) BSA (Sigma for $30 \mathrm{~min}$. In addition, an avidinbiotin block was performed using an Avidin-Biotin blocking kit (Vector Laboratories Inc., Peterborough, UK) according to the manufacturer's specifications.
The sections were then incubated overnight at $4{ }^{\circ} \mathrm{C}$ in immunostaining chambers (Shandon, coverplate Anatomical International, Runcorn, UK) with rabbit polyclonal anti-PR antibody (PR (C-19): sC-538, diluted in a ratio of 1:500) (Santa Cruz Biotechnology Inc., Santa Cruz, CA, USA). After three washes in TBS, the sections were incubated with a secondary antibody, swine antirabbit biotinylated (diluted in a ratio of 1:500; E0353, DAKO, Ely, UK) diluted in NPS for $30 \mathrm{~min}$, followed by three washes with TBS. The sections were incubated in ABC HRP (DAKO, K0355) for 30 min. All sections were washed three times in TBS and immunostaining was developed using Liquid DAB + (Dako) until staining was optimal. After about $5 \mathrm{~min}$, the reaction was stopped by immersing sections in tap water. The sections were counterstained with haematoxylin, dehydrated in a graded ethanol series, cleared in xylene and a cover slip applied using Pertex mounting medium (CellPath plc, Hemel Hempstead, UK).

The protocol for localisation of ER $\alpha$ was similar with a few minor differences. The serum block was a normal rabbit serum (NRS, diluted in a ratio of 1:5 in TBS containing 5\% (w/v) BSA (Sigma) and the secondary antibody was rabbit anti-mouse biotinylated (RAMB, diluted in a ratio of 1:500 in NRS, Dako, E0464). Avidin diluted in NRS was added to the sections and incubated for $30 \mathrm{~min}$ at room temperature. The sections were washed three times with TBS. Biotin diluted in NRS was added to the sections and incubated for $20 \mathrm{~min}$ followed by three washes with TBS. The mouse monoclonal ER $\alpha$ antibody (NCL-ER-6F11/2, Novocastra Laboratories Ltd, Newcastle upon Tyne, UK) diluted in a ratio of 1:50 in NRS, and used previously (McKinnell et al. 2001), was added to the sections which were incubated overnight at $4{ }^{\circ} \mathrm{C}$. Day 2 of the protocol was identical to that performed for PR.

The protocol to localise ER $\beta$ was similar to the one for $E R \alpha$, but antigen retrieval was performed using $0.01 \mathrm{M}$ glycine/EDTA buffer ( $\mathrm{pH}$ 3.5). After blocking with NRS, the sections were incubated overnight with the mouse anti-human ER $\beta 1$ (MCA1974S, clone PPG5/10, Serotec, Düsseldorf, Germany; Sierens et al. 2004), diluted in a ratio of 1:60. Day 2 of the protocol was identical to that performed for $E R \alpha$, using the same secondary antibody. To determine the specificity of the antibodies, the primary antibody was replaced with appropriate rabbit immunoglobulin G (IgG; Dako), or mouse IgG (Vector) at the same concentration as the primary antibody.

\section{Analysis of receptor staining}

Immunocytochemistry staining was analysed by using a microscope (Axiostar; Zeiss, Jena, Germany). Both authors independently examined the uterus systematically while being blinded to the status of the animal from which the tissue was obtained. The scores 
(see below) were assigned by each examiner. These were generally in excellent agreement. Where differences in score arose, the specimen was checked so that agreement could be reached. The mean values from the two scorers were taken for the final result. Each specimen was morphologically evaluated by division into six anatomic zones: (1) the luminal epithelium, (2) the stroma adjacent to the luminal epithelium, (3) glands of the upper zone, or functionalis (4) the stroma in the functionalis region, (5) the glands of the lower zone, or basalis and (6) the stroma in the basalis region. The functionalis glands were delineated by their oval shape, while the basalis glands tended towards being longitudinal (Rowe et al. 2004). The division of the glands into a single zone in the basal layer, rather than two layers as observed in higher primates has been established in previous studies (Rune et al. 1992). In addition, by weeks 3 and 4 of pregnancy, decidualised cells were clearly recognisable.

Each zone was given an intensity score and a proportional score to provide a staining index. The intensity score reflected the intensity of the brown positive staining in the cell nuclei on a scale of 0 (no staining), 1 (light), 2 (moderate) or 3 (strong), while the proportional score reflected the percentage of cell nuclei that stained positive in the different groups of cells. The percentage score was converted to the scale 0 to 3 and added to the intensity score for each observation to produce a 'staining index'. For example, if $50 \%$ of cells were stained strongly, the intensity score would be $1.5+$ 3 . Thus, the maximum intensity score was 6 . Values for each group were calculated as means and standard error. In general, changes in percentage score were similar to those in staining intensity. The method was a simplified adaptation of the HSCORE (Murray et al. 1999). In the latter method, account is also taken of variations in staining intensity within the percentage of cells showing positive staining. As the intensity was fairly uniform within a compartment in individual sections we omitted this step in our calculations.

After examination, representative sections were photographed using a Provis microscope (Olympus Optical, London, UK) fitted with a digital camera (DC S330; Eastman Kodak). The captured images were transferred to a computer (G4; Apple Computer Inc., Cupertino, CA, USA) and compiled using Photoshop 5.0 (Adobe Systems Inc).

\section{Steroid assays}

Oestradiol concentrations in serum collected by exsanguination were determined by an ELISA assay described previously (Taylor et al. 2004), all samples being run in a single assay. Plasma progesterone concentrations in routine samples to determine cycle stage were determined by an ELISA assay as previously described (Wulff et al. 2001).

\section{Statistical analysis}

The significance of differences between means for plasma hormone concentrations were determined by ANOVA followed by Bonferroni's post-test with $P<0.05$ being considered significant. Differences in staining index between the groups was performed by using the non-parametric Mann-Whitney $U$-test, $P<0.05$ being considered to reflect a significant difference from the control group or between groups.

\section{Results}

Plasma concentrations of oestradiol and progesterone were as expected from stage of the cycle (Fig. 1). Oestradiol rose significantly $(P<0.001)$ from the midproliferative phase to the late proliferative peak before falling significantly $(P<0.01)$ at the early secretory phase; levels during pregnancy were similar to the mid-secretory phase. Ovariectomy, GnRH antagonist and VEGF Trap treatment all significantly reduced $(P<0.001)$ the oestradiol levels when compared with the late proliferative phase. Progesterone concentrations were elevated during the secretory phase and maintained during early pregnancy.

For each receptor, photomicrographs are depicted for the stages which demonstrated the predominant changes in staining index, namely, mid-proliferative, early secretory, late secretory and week 4 of pregnancy. The staining index for each receptor in the basalis glands, functionalis glands, stroma in the basalis region and stroma in the functionalis region is shown for all stages in the accompanying histograms. Since staining indices for the luminal epithelium and stroma next to the luminal epithelium changed in a manner similar to that of the functionalis glands and stroma next to these glands, data for the former parameters are not shown.

PR in all epithelial compartments increased $(P<0.01)$ between the mid-proliferative phase and late proliferative phase, most markedly in the functionalis (Fig. 2). After the early secretory phase, a significant decline in PR occurred during the remainder of the cycle and pregnancy with the luminal epithelium being most affected, followed by the functionalis glands. The glands of the basalis region, especially those nearest to the myometrium retained receptor for the longest, not becoming significantly reduced until the late secretory phase $(P<0.05)$, and disappearing by week 4 of pregnancy $(P<0.01)$.

In contrast to the glands, PR expression was present in stroma at the mid-proliferative phase. In the stroma basalis region, PR tended to be low, but was only significantly lower $(P<0.01)$ than maximal values at the late secretory phase. A consistent significantly lower $(P<0.05)$ expression was observed at 2 and 3 weeks of pregnancy. In the stromal functionalis, PR was highly expressed and was largely unaffected by stage, except at 

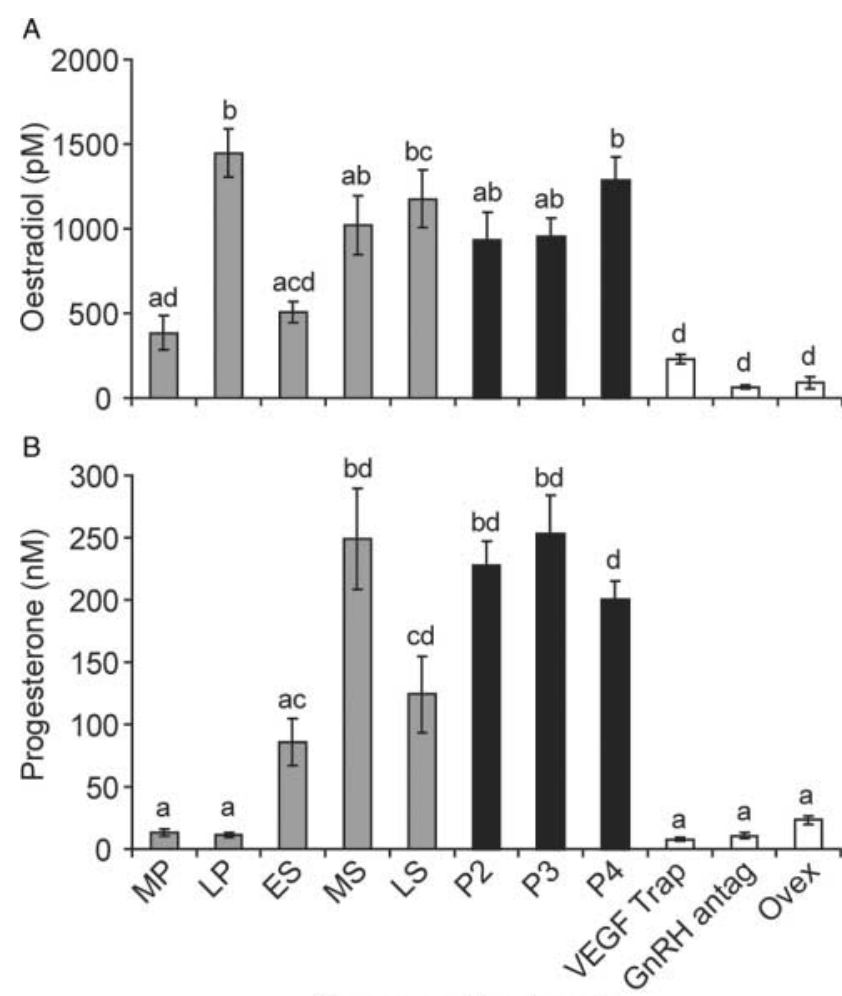

Stages and treatment

Figure 1 Plasma concentrations of $(\mathrm{A})$ oestradiol and (B) progesterone at the time of collection of the uterus in marmosets at the mid-proliferative (MP), late proliferative (LP), early, mid- and late secretory phases

(ES, MS, LS) of the ovulatory cycle, at weeks 2, 3 and 4 of pregnancy (P 2, 3 and 4) and after treatment with VEGF Trap, GnRH antagonist, or ovariectomy initiated at the late luteal phase. Values are means \pm s.E.M. Columns with different letters are significantly different.

the late secretory phase which was significantly lower $(P<0.05)$ than the proliferative phase values. The large decidualised cells observed by weeks 3 and 4 of pregnancy were negative; however, small cells present in the decidualised zone, presumably fibroblasts, were strongly stained for PR. In some sections, in particular in pregnancy, and after reduction in oestradiol, a weak cytoplasmic stain was noted. This was ignored for the purposes of quantification.

After treatment with VEGF Trap, GnRH antagonist or ovariectomy, the late proliferative rise in PR in epithelial cells was significantly inhibited $(P<0.05)$ in all compartments (Fig. 3) when compared with the late proliferative phase control. Similar inhibitory effects were observed in the stromal zones.

$\mathrm{ER} \alpha$ expression in the basalis and functionalis glands increased from the mid- to late proliferative phase $(P<0.01$ and $P<0.05$ respectively) as the cycle progressed to the early secretory phase, and then significantly declined $(P<0.05)$ at the late secretory phase (Fig. 4) when residual expression was largely in the epithelial cells of basalis glands that were nearest to the myometrium. Expression of ER $\alpha$ also declined as pregnancy progressed, most markedly in the functionalis glands with weeks 2, 3 and 4 being significantly lower $(P<0.05)$ than the proliferative and early secretory phases and with week 4 also being lower $(P<0.01)$ than the mid-secretory phase. In basalis glands, the decline in $E R \alpha$ in the late secretory phase was less marked. By 3 weeks of pregnancy, basalis gland expression was significantly lower $(P<0.05)$ than the late proliferative and early secretory phases, and by 4 weeks expression had declined $(P<0.01)$ further. In the stromal basalis zone, expression was highest during the proliferative phase, declining markedly $(P<0.01)$ by the early-secretory phase, with further significant $(P<0.05)$ reductions by the mid-secretory phase. An absent or very low expression was maintained during early pregnancy. In the stromal functionalis, a significant increase $(P<0.01)$ in expression occurred between the mid- and late proliferative phases but declined by the early secretory phase $(P<0.05)$. Expression was maintained at secretory phase levels at weeks 3 and 4 of pregnancy. ER $\alpha$ was not detected in decidual cells.

After treatment with VEGF Trap, GnRH antagonist or ovariectomy, expression of $E R \alpha$ was maintained in all epithelial layers, there being no significant differences to late proliferative controls in any parameter except a small rise $(P<0.05)$ in staining index in basalis glands after $\mathrm{GnRH}$ antagonist (Fig. 5). Similarly, stromal staining was largely unaltered, except for a significant decline in expression $(P<0.05)$ in the ovariectomised animals in the functionalis area.

ER $\beta$ was present throughout the endometrium and staining index for ER $\beta$ in the epithelium was less responsive to stage of the reproductive cycle than $E R \alpha$ (Fig. 6). In the basalis glands, staining index was maintained throughout the cycle with a slightly reduced expression $(P<0.05)$ at weeks 3 and 4 of pregnancy. In the epithelium of the functionalis glands, staining index showed a small increase $(P<0.05)$ between the early proliferative and mid-secretory phase and was maintained during pregnancy. In the stroma between all compartments, ER $\beta$ expression significantly increased $(P<0.05)$ between the mid- and late proliferative phases. After this peak, levels significantly declined $(P<0.01)$ again to the late secretory phase, with levels being largely maintained at secretory phase values in pregnancy. The large decidualised cells observed by weeks 3 and 4 of pregnancy were strongly stained for ER $\beta$ (Fig. 6J).

After treatment with VEGF Trap, GnRH antagonist or ovariectomy, $E R \beta$ in the basalis glands was not significantly altered but in the functionalis glands was significantly lower; VEGF Trap and ovariectomy $(P<0.01)$, and $\mathrm{GnRH}$ antagonist $(P<0.05 ;$ Fig. 7$)$. In the stroma next to the lumen and the functionalis zone, all three treatments caused a significant suppression $(P<0.01)$ in the staining index, while in the stroma of the basalis zone this effect was significant $(P<0.05)$ only for VEGF Trap. 


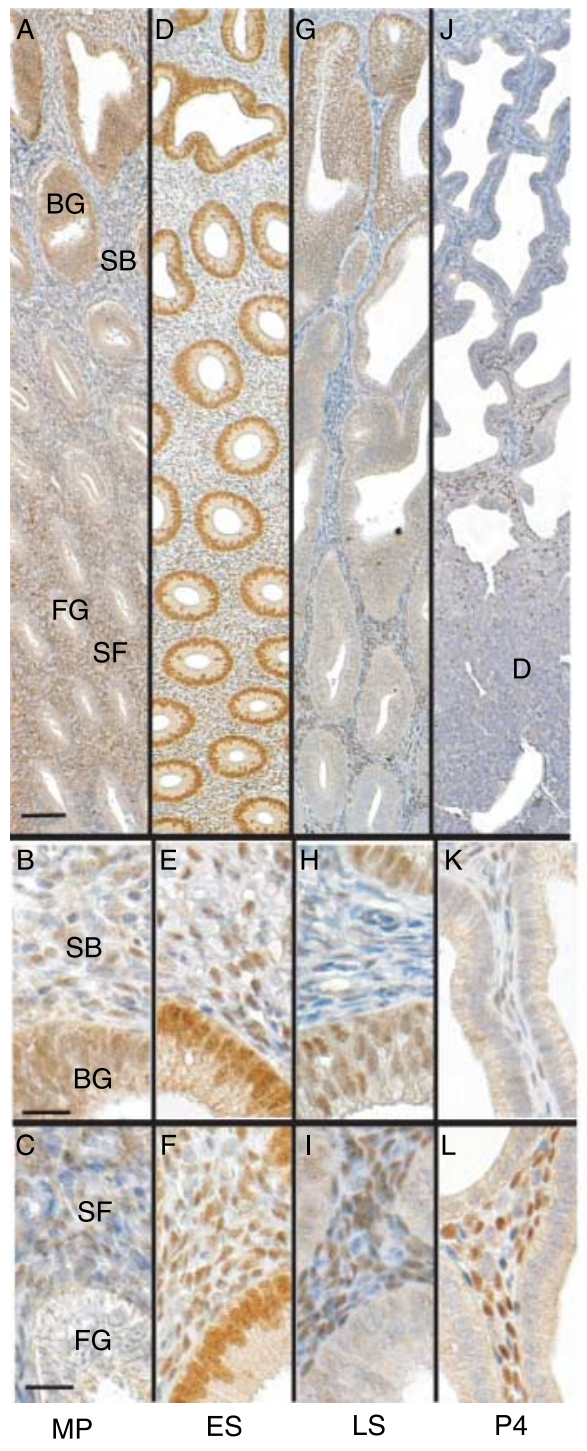

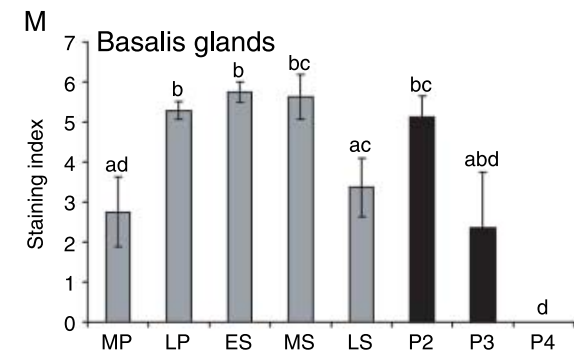

$\mathrm{N}$
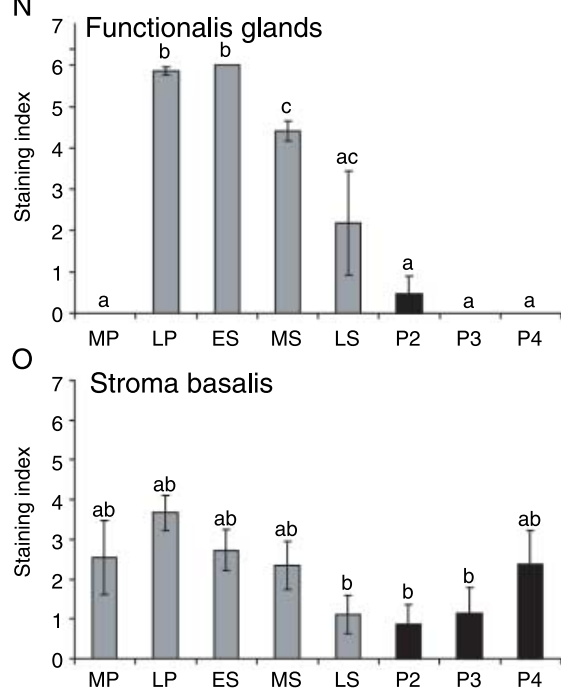

$\mathrm{P}$

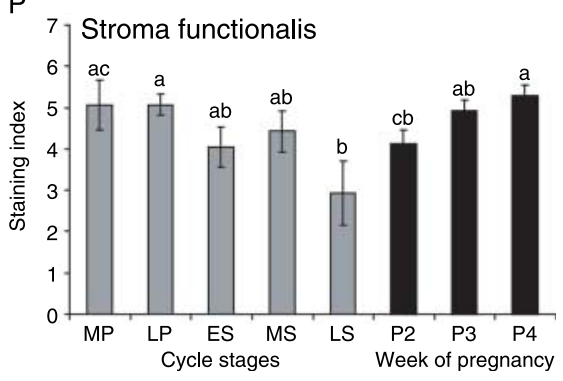

Figure 2 Immunochemical localisation of PR (brown) in sections of marmoset endometrium counterstained with haematoxylin (blue) from (A-C) mid-proliferative phase (MP), (D-F) early secretory phase (ES), (G-I) late-secretory phase (LS) and (J-L) week 4 of pregnancy (P4). The top row is of low magnification to show distribution throughout the endometrium. High power magnifications of the epithelial and stromal cells of basalis and functionalis regions are shown in the middle and bottom panels respectively. Basalis glands (BG), functionalis glands (FG), stroma in functionalis zone (FG) and stroma of basalis zone (SB) are identified in the left-hand panels. Changes in staining intensity are shown in (M-P). Grey columns show data for the normal cycle, black show values at weeks 2 (P2), 3 (P3) and 4 (P4) of pregnancy. Top panel, scale bar $=200 \mu \mathrm{m}$; middle and lower panels, scale bar $=20 \mu \mathrm{m}$. Values are means \pm s.E.M. Panels with different letters are significantly different.
A closer examination of the patterns of staining in the stroma revealed that neither PR nor ER $\alpha$ was expressed in endothelial cells, while a proportion of perivascular cells was positively stained. In contrast, ER $\beta$ was expressed in the majority of endothelial cells in addition to a proportion of the surrounding stroma (Fig. 8). This arrangement was maintained in the large maternal vessels (Fig. 8). Changes in the intensity of $E R \beta$ in endothelial cells after VEGF Trap, ovariectomy or GnRH antagonist appeared similar to the other stromal populations (not shown).

Pseudostratification was common in glands during the secretory phase, especially in the basalis zone. This is best illustrated in the sections shown in Fig. 4 D, G,E and $\mathrm{H}$. The magnitude of pseudostratification appeared to increase as the secretory period progressed. By the late secretory phase, pseudostratification was also observed in the luminal epithelium (not shown).

\section{Discussion}

This is the first detailed analysis of the localisation of ER and PR in the marmoset endometrium. We demonstrate how synchronisation of the cycle by treatment with a luteolysis-inducing prostaglandin allows collection of tissue at precise stages. Despite the marmoset having distinct differences in some of the mechanisms in the way the ovarian hormones are processed at the receptor level, the pattern of steroid receptor localisation is generally similar to that observed in women and for other non-human primates studied to date.

The most dramatic changes during the cycle were observed for PR, which increased markedly in all epithelial compartments between the mid-proliferative phase to the late proliferative phase. Staining index declined after the early secretory phase with the luminal epithelium and the functionalis glands being most 

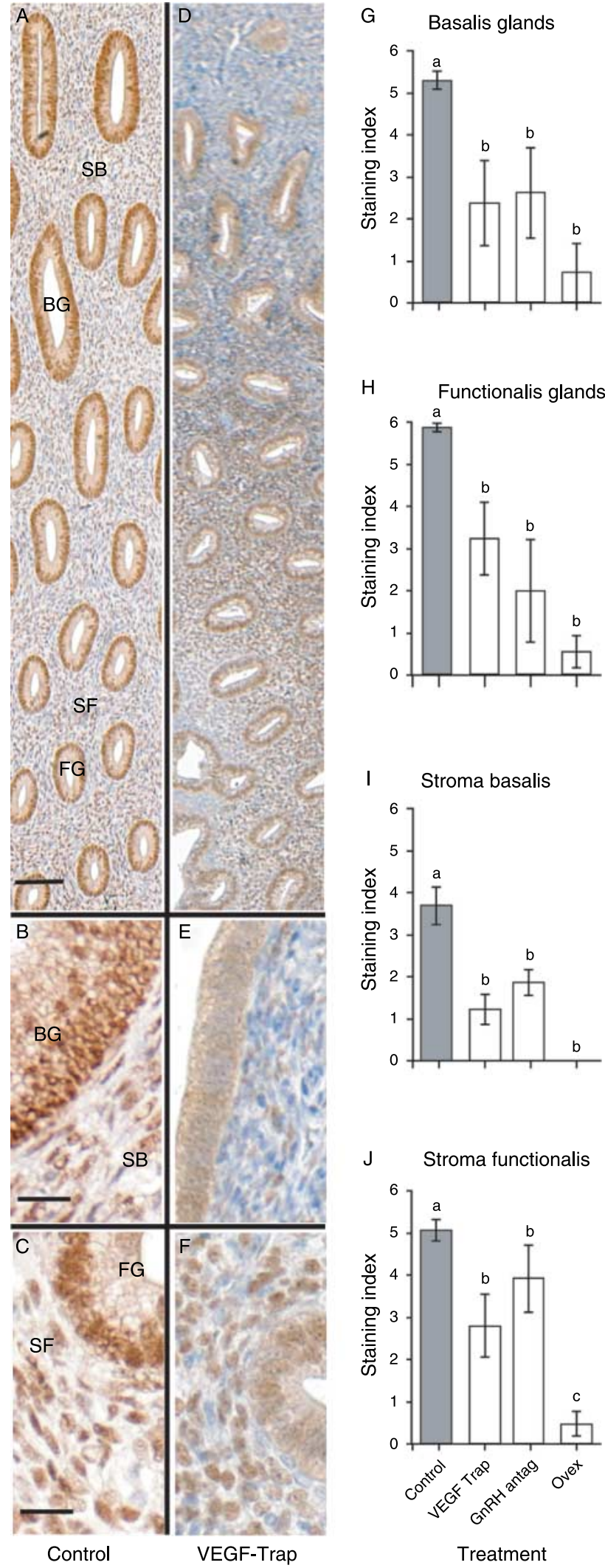

$\mathrm{H} \quad$ Functionalis glands

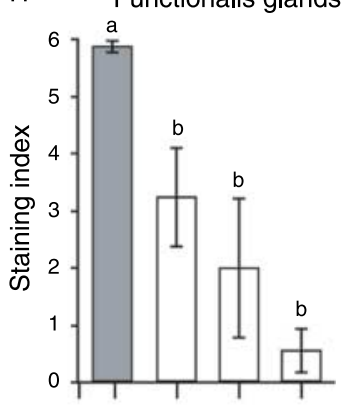

I Stroma basalis

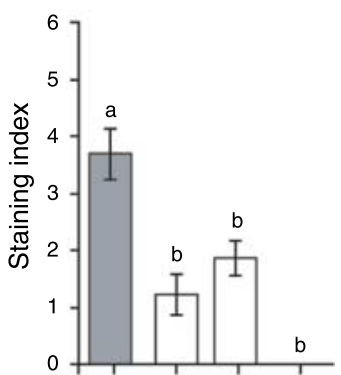

J Stroma functionalis

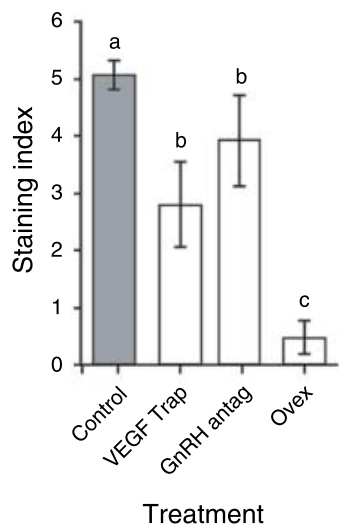

Figure 3 Immunochemical localisation of PR (brown) in sections of endometrium from a control marmoset in the late proliferative phase and after treatment with VEGF Trap. Changes in staining index for PR affected. The increase in PR in epithelium from the midto late proliferative phase is a consequence of oestrogen stimulation, while its decline in the glands in the secretory phase is attributed to the exposure to progesterone (Jabbour et al. 2006). A relative resistance to PR decline in the basalis epithelium is also observed in baboons (Hild-Petito et al. 1992). The maintenance of PR in the stroma during the secretory phase, in contrast to its reduction in the glands, is also found in women, macaques and baboon (e.g. Hild-Petito et al. 1992, Jabbour et al. 2006).

$E R \alpha$ increased in the glands and stroma during the proliferative phase. Like $\mathrm{PR}, \mathrm{ER} \alpha$ declined as the secretory phase progressed, presumably also as a result of exposure to high levels of progesterone. In contrast to $\mathrm{PR}, \mathrm{ER} \alpha$ also declined markedly in the stroma by the mid-secretory phase. This is similar to macaques (Brenner \& Slayden 1994) and women (Lecce et al. 2001). ER $\beta$ was consistently highly expressed throughout the cycle in the epithelial cells and contrasted with ER $\alpha$ in maintaining a high staining index throughout the secretory phase. However, in stroma, expression gradually declined as the secretory phase progressed in a pattern similar to $E R \alpha$, implying a negative regulation of ER $\beta$ by progesterone in stroma but not in epithelial cells. Although we found ER $\beta$ to be highly expressed in the endometrium, as in the human and macaque (Crithcley et al. 2001) it has been suggested that it has a minor function in this tissue when compared with ER $\alpha$ (Harris 2007). These conclusions are based largely on studies in the ER $\beta$ knockout mouse and its potential role in the primate endometrium must be determined by use specific of $E R \alpha$ and $E R \beta$ antagonists.

In pregnancy, PR-staining index declined rapidly in the functionalis glands, slowly in basal glands and had disappeared by pregnancy week 4. PR expression was maintained in the stroma during pregnancy, and at week 4 was significantly higher in the functionalis zone than the late secretory phase. Thus, despite the high plasma levels of oestradiol, the PR-staining index in epithelial cells declines during pregnancy suggesting the downregulation of the receptor is related to the duration of exposure to progesterone. These findings are similar to those in the baboon (Hild-Petito et al. 1992). ER $\alpha$ expression steadily declined in the glands as pregnancy progressed. Thus, contrasted with the stroma where it was absent at 2 weeks but recovered thereafter. Recently, RT-PCR analysis of uterine expression of ER $\alpha$ and PR from marmosets in the mid-secretory phase and pregnancy revealed no apparent differences in mRNA

after treatment with VEGF Trap, GnRH antagonist or ovariectomy for 10 days (open column) when compared with late proliferative controls (shaded columns). $N=4$ per group. Other details as provided in Fig. 2. Top panel, scale bar $=200 \mu \mathrm{m}$; middle and lower panels, scale bar $=$ $20 \mu \mathrm{m}$. Values are means \pm S.E.M. Panels with different letters are significantly different. 


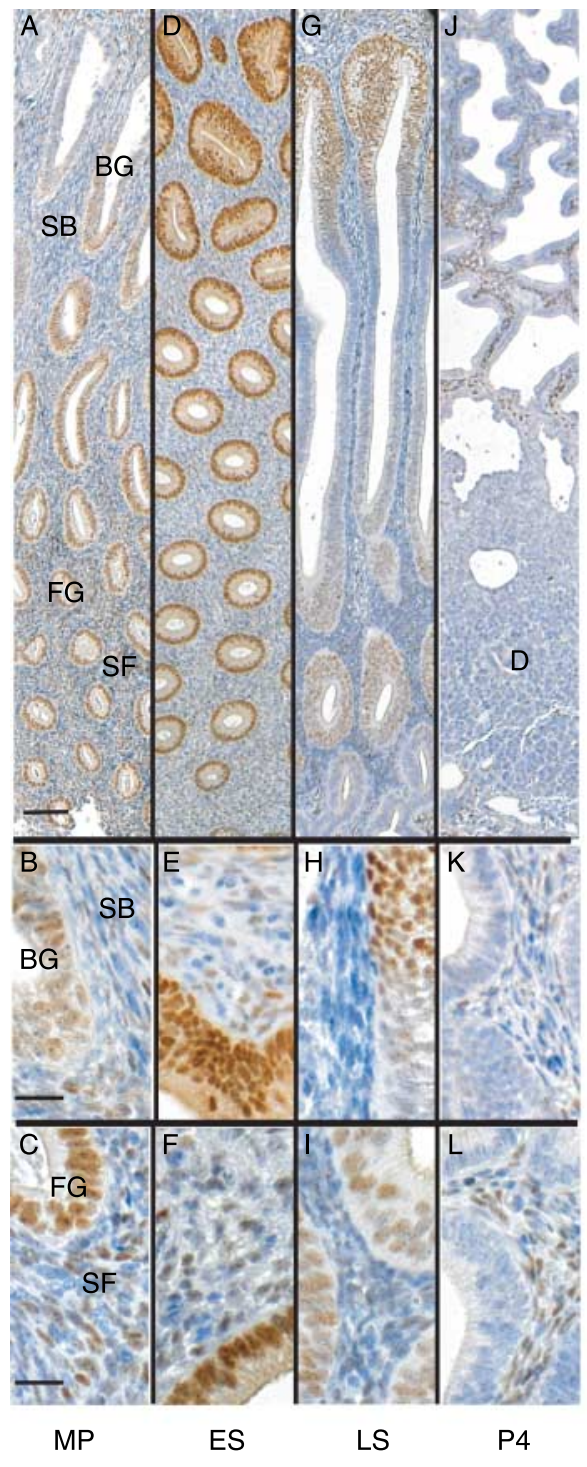

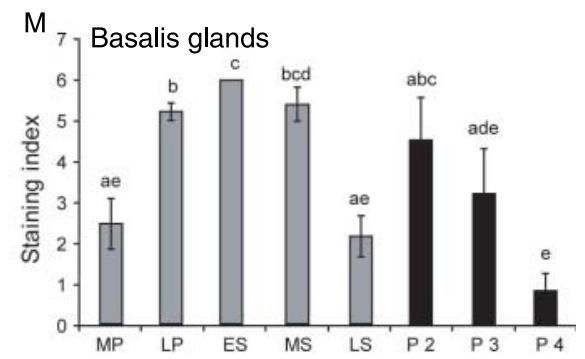

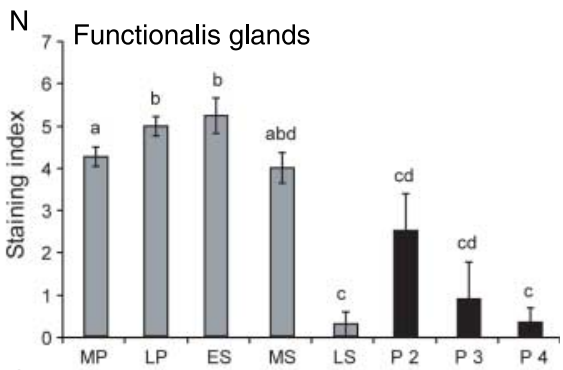

$\mathrm{O}$
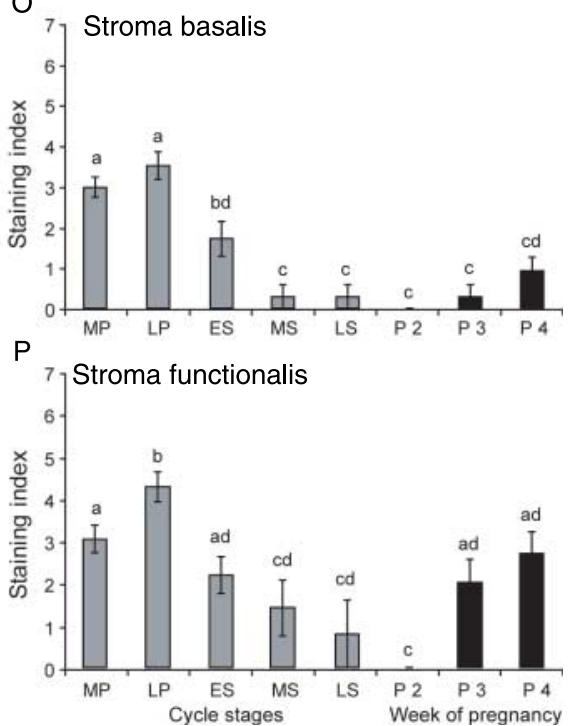

Figure 4 Immunochemical localisation of $E R \alpha$ (brown) in sections of marmoset endometrium counterstained with haematoxylin (blue) from (A-C) mid-proliferative phase (MP), (D-F) early secretory phase (ES), (G-I) late secretory phase (LS) and (J-L) week 4 of pregnancy (P4). The top row is of low magnification to show distribution throughout the endometrium. High power magnifications of the basalis and the functionalis regions are shown in the middle and bottom panels respectively. Basalis glands (BG), functionalis glands $(\mathrm{FG})$, stroma in functionalis zone (FG) and stroma of basalis zone (SB) are identified in the left-hand panels. Changes in staining intensity are shown in (M-P). Grey columns show data for the normal cycle, black show values at weeks 2 (P2), 3 (P3) and 4 (P4) of pregnancy. Top panel, scale bar $=200 \mu \mathrm{m}$; middle and lower panels, scale bar $=20 \mu \mathrm{m}$. Values are means \pm S.E.M. Panels with different letters are significantly different.
(Einspanier et al. 2006b). The presence of ER $\beta$ in the decidua in the absence of ER $\alpha$ agrees with observations in the human (Milne et al. 2005), while the numbers of decidualised cells staining for PR in the marmoset appears to be less.

To obtain further insight into the role of oestradiol in stimulating these changes, ovariectomy, $\mathrm{GnRH}$ antagonist or VEGF Trap treatment was carried out at the late secretory phase to remove or suppress the secretion of ovarian hormones. Endometrium was studied 10 days later, equivalent to the late proliferative phase in controls in which luteal function had been terminated by prostaglandin treatment 10 days previously. Oestrogen is responsible for endometrial proliferation and induces its own receptor (Jabbour et al. 2006), but despite deprivation of ovarian oestradiol, the staining index for $\mathrm{ER} \alpha$ was similar to the oestradiol-stimulated late proliferative levels in all areas. It should be noted that at the end of the 10-day period of oestradiol deprivation, ER $\alpha$-staining index was higher than at the time of onset of the treatments at the late secretory phase. The only site where $E R \alpha$ was decreased was the stroma in the functionalis area in the ovariectomised group. In contrast, the induction of expression of PR in both epithelial cells and stroma was prevented by these treatments. These observations confirm the rise in PR and require the follicular phase rise in oestrogen. However, they show that the rise in ER $\alpha$ does not have this dependence. Thus, it appears to be driven either by progesterone withdrawal or requires only residual amounts of oestrogen that may remain available from the circulation or by enzyme conversion with the endometrium during the 10-day period following ovariectomy.

That a reduction in plasma progesterone has an important role in stimulating expression of $E R \alpha$, is also 

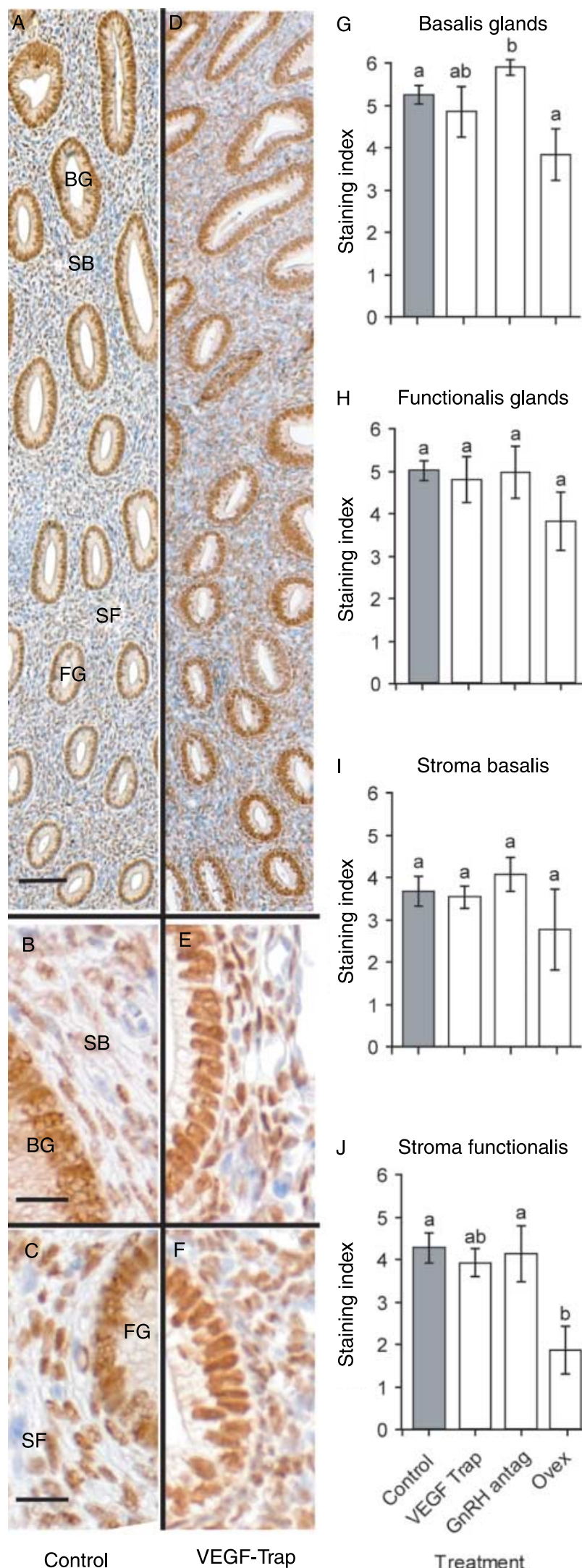

$\mathrm{H} \quad$ Functionalis glands
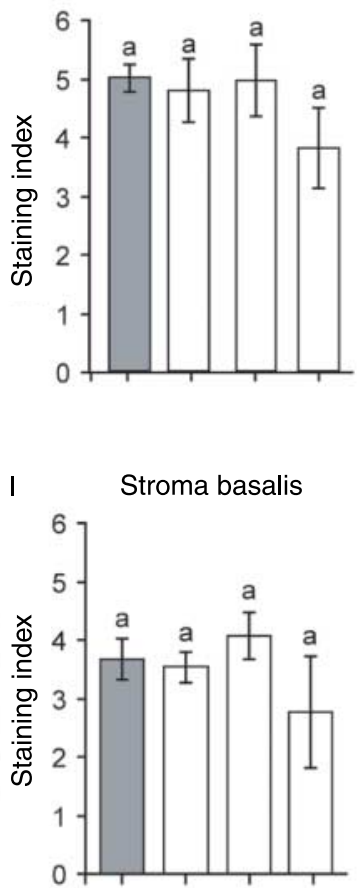

\section{J Stroma functionalis}

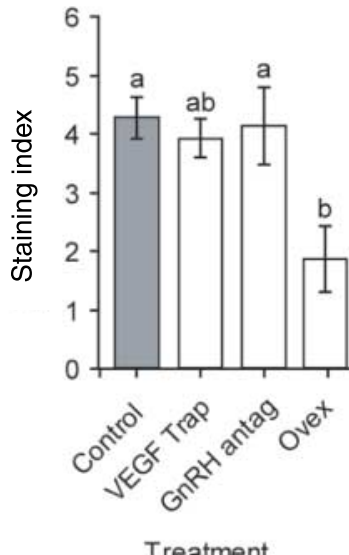

Figure 5 Immunochemical localisation of ER $\alpha$ (brown) in sections of endometrium from a control marmoset in the late proliferative phase implied by the fact that, while expression is very low in the functionalis glands at the progesterone-dominated late secretory phase, $E R \alpha$ is more rapidly restored than that of $\mathrm{PR}$, being present by the mid-proliferative phase in intact animals, while PR expression was minimal. The reduction in $\mathrm{PR}$ at the end of the cycle removes the progesterone block to $E R \alpha$ synthesis and leads to $E R \alpha$ expression by the onset of the subsequent proliferative phase, followed by PR expression. The presence of ER $\alpha$ expression on one hand, associated with a decline in PR expression on the other after ovariectomy, is similar to findings in the atrophic endometrium of post-menopausal women (Snijders et al. 1992) and the ovariectomised baboon (Hild-Petito et al. 1992). It should also be considered that these treatments result in a less extensive and endometrium than is observed under cyclic conditions. It seems that the remaining population of cells may be particularly resistant in terms of maintaining ER $\alpha$ expression.

In contrast to $E R \alpha$, the staining index for $E R \beta$ was reduced in the epithelium of the functionalis and in the stroma by all three treatments while VEGF Trap also resulted in a decline in ER $\beta$ in the luminal epithelium. Although not as markedly suppressed as the PR, these results provide evidence that ER $\beta$ expression also appears to be oestrogen dependent over short time periods.

Since PR expression requires oestrogen stimulation, the prevention of the rise in PR by the treatments suggests that this requires a higher level of oestrogen than does the maintenance of the ERs. The suppression in PR was most profound in the endometrium overall in the ovariectomised marmosets suggesting that the higher residual levels of oestradiol present after VEGF Trap and $\mathrm{GnRH}$ antagonist treatment afforded a degree of stimulation of the PR.

Oestradiol and progesterone are considered to be important in the regulation of the endometrial vasculature, although their exact roles have yet to be defined (Nayak \& Brenner 2002, Jabbour et al. 2006). A distinctive feature of endometrial endothelial cells of the marmoset was the preferential staining for ER $\beta$ over $\mathrm{PR}$ or $\mathrm{ER} \alpha$ at all stages of the cycle and during pregnancy. This phenomenon has been described in women (Critchley et al. 2001, Lecce et al. 2001) and macaques (Brenner \& Slayden 2004), and has been confirmed by studies on human microvascular endometrial endothelial cell (HEEC) cultures (Krikun et al. 2005). This suggests a role for oestrogen directly upon endometrial

and after treatment with VEGF Trap. Staining index for ER $\alpha$ after treatment with VEGF Trap, GnRH antagonist or ovariectomy for 10 days (open columns) when compared with late proliferative controls (shaded columns). Staining is largely retained despite treatments. Top panel, scale $b a r=200 \mu \mathrm{m}$; middle and lower panels, scale bar $=20 \mu \mathrm{m}$.

Values are means \pm s.E.M. Panels with different letters are significantly different. 


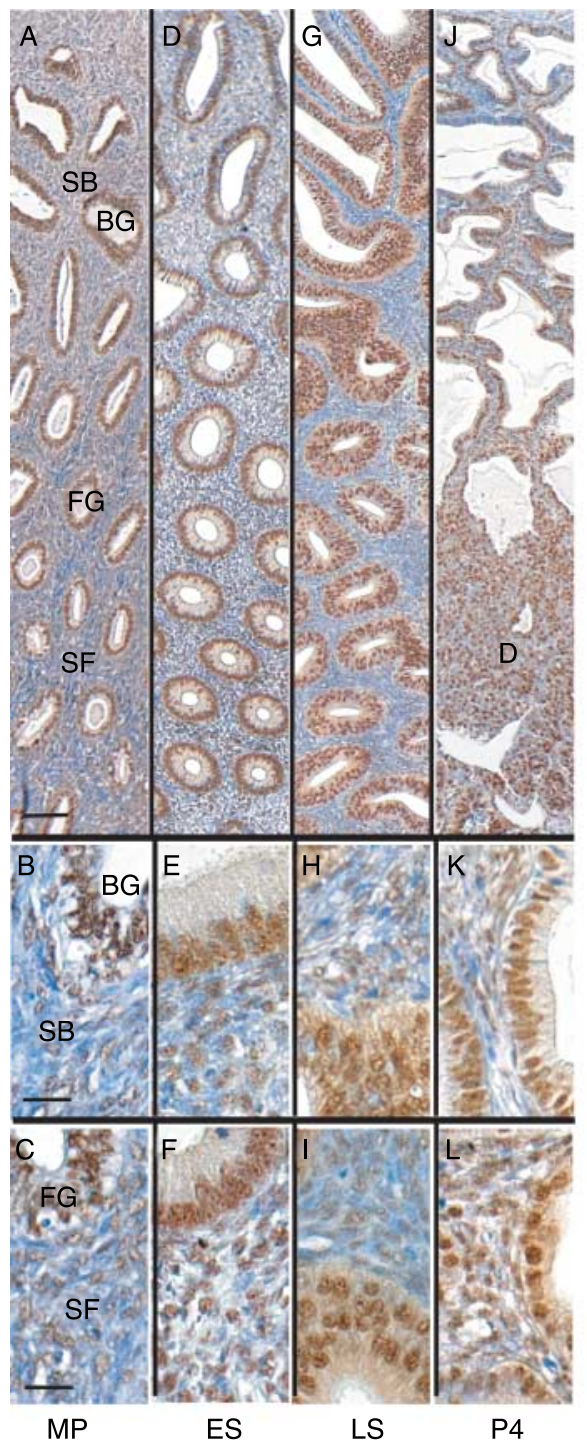

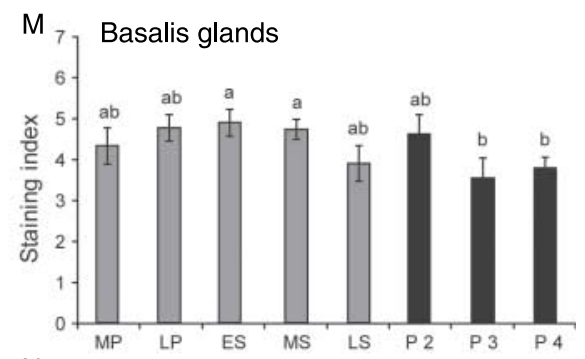

$\mathrm{N}$
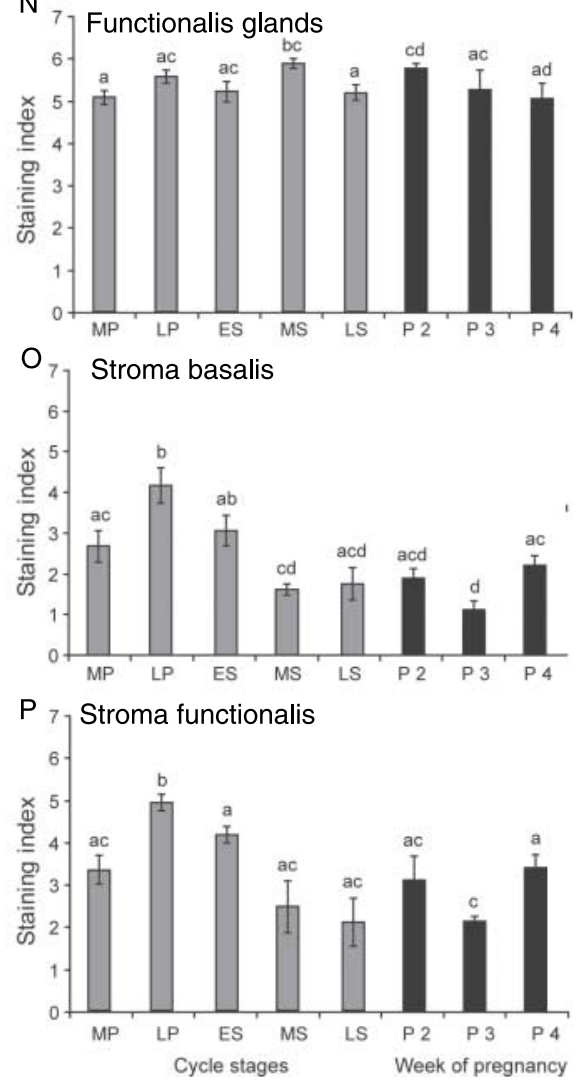

Figure 6 Immunochemical localisation of ER $\beta$ (brown) in sections of marmoset endometrium counterstained with haematoxylin (blue) from (A-C) mid-proliferative phase, (D-F) early secretory phase, (G-I) late-secretory phase and (J-L) week 4 of pregnancy. The top row is a low magnification to show distribution throughout the endometrium. High power magnifications of the basalis region and functionalis region are shown in the middle and bottom panels respectively. Basalis glands (BG), functionalis glands (FG), stroma in functionalis zone (FG) and stroma of basalis zone (SB) are identified in the lefthand panels. Changes in staining intensity are shown in (M-P). Grey columns show data for the normal cycle, black columns show values at weeks 2 (P2), 3 (P3) and 4 (P4) of pregnancy. Top panel, scale bar= $200 \mu \mathrm{m}$; middle and lower panels, scale bar $=20 \mu \mathrm{m}$. Values are means \pm s.E.M. Panels with different letters are significantly different. endothelial cells influencing angiogenesis and vascular permeability. Ovariectomy, GnRH antagonist or VEGF Trap treatment all caused a decline in expression of ER $\beta$ in the stroma and as higher staining intensity in endothelial cells when compared with other cells in the stroma after these treatments was not apparent it suggests that the expression of endothelial ER $\beta$ receptor is oestrogen-dependent. Although VEGF is the principal angiogenic factor which acts upon endothelial cells (Ferrara 2004), VEGF Trap treatment did not appear to result in preferential suppression of the endothelial ER $\beta$ receptor, suggesting that the effect observed was the result of reduction in oestradiol stimulation. The extent to which oestrogen action on the endothelium is primarily mediated via VEGF remains to be established.

In addition to inhibition of VEGF leading to a reduced ovarian steroid stimulation to the endometrium, this angiogenic growth factor also has direct actions on endometrium, which are currently being explored. VEGF is synthesised in both the stroma and epithelial cells (Rowe et al. 2003). The principal actions are likely to be on endometrial endothelial cells, mediated by VEGF receptors (Nayak \& Brenner 2002, Rowe et al. 2003). A link between oestrogen action on endometrial endothelial cells and expression of VEGF, other angiogenic factors or their receptors has yet to be established as addition of oestrogen to HEEC cultures failed to alter their expression levels (Krikun et al. 2005).

With respect to previous studies on location of steroid receptors in the marmoset uterus, the finding of highest levels of ER $\alpha$ in stroma during the late proliferative phase agrees with Kholkute et al. (2000) but as these authors failed to detect expression of either ER $\alpha$ or PR in the epithelial cells or detect ER $\alpha$ during the secretory phase in either stroma or glands, it would seem that the antibodies used or technical conditions were sub-optimal. In a 

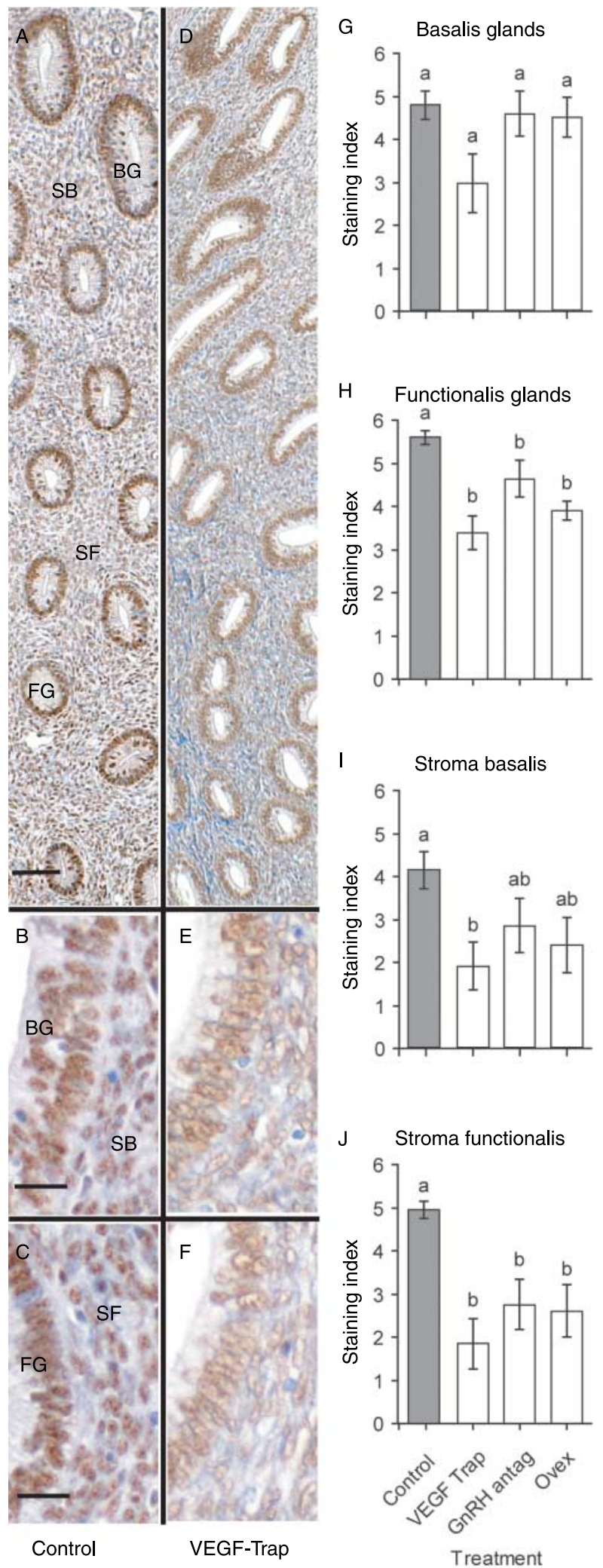

Figure 7 Immunochemical localisation of ER $\beta$ (brown) in sections of endometrium from a control marmoset in the late proliferative phase and after treatment with VEGF Trap. Changes in staining index for ER $\beta$ after treatment with VEGF Trap, GnRH antagonist or ovariectomy for subsequent study, localisation of $E R \alpha$ and $P R$ in epithelium of the marmoset was established (Narkar et al. 2006). However, the occurrence of high levels of PR in glands during the early proliferative and late secretory phases and low levels in the stroma contrast with the current report, as does the finding of a reduction in $E R \alpha$ in the late proliferative phase. No quantitative Statistical analysis was performed and there was insufficient detail for direct comparison with the current report.

With respect to differences between the pattern of ER and $\mathrm{PR}$ in the marmoset endometrium, to those in other primates, the low level of epithelial PR at the midproliferative phase is lower than the human, while the decline in PR during the secretory phase appears to lag behind (Snijders et al. 1992). These differences may reflect the longer period to implantation (11 days) in the marmoset and the longer (20-day) luteal phase. In early pregnancy, the marmoset seems to maintain a level of $E R \alpha$ expression that is not observed in baboon endometrium (Hild-Petito et al. 1992). Pseudostratification was common in glands of the marmoset during the secretory phase, especially in the basalis zone, a phenomenon reported in the vervet monkey (Caroll et al. 2007) but not noted in macaques or human. We have observed continued proliferation of epithelial cells in the marmoset in the early secretory phase (H M Fraser, unpublished observations) and this may account for the build up in cell layers. Another difference was the apparent absence of decidualisation of the endometrium in the normal cycle although the phenomenon was readily apparent in early pregnancy. The absence of decidualisation in the absence of pregnancy constitutes a significant difference to the human, macaques and baboon (Dunn et al. 2003), and is perhaps related to the more superficial nature of implantation in the marmoset. Finally, ER $\beta$ expression has also been reported in natural killer cells in the human endometrium (Henderson et al. 2003), but we have been unable to detect this cell type in the marmoset endometrium.

In conclusion, the localisation of ER and PR in the marmoset endometrium, reveals a predominantly similar profile to the human. The studies using VEGF Trap and $\mathrm{GnRH}$ antagonist are examples of situations in which the effects of a novel compound that could impact on endometrial function may be explored. For example, the localisation of ER $\beta$ receptors on endothelial cells of the marmoset endometrium should provide a valid model system in which their role in regulation of the uterine vasculature may be investigated. Use of the marmoset as a non-human primate model in female reproduction continues to expand; recently, it has been demonstrated that endometriosis can be induced in this species

10 days (open column) when compared with late proliferative controls (shaded columns). Top panel, scale bar $=200 \mu \mathrm{m}$; middle and lower panels, scale bar $=20 \mu \mathrm{m}$. Values are means \pm s.E.M. Panels with different letters are significantly different. 

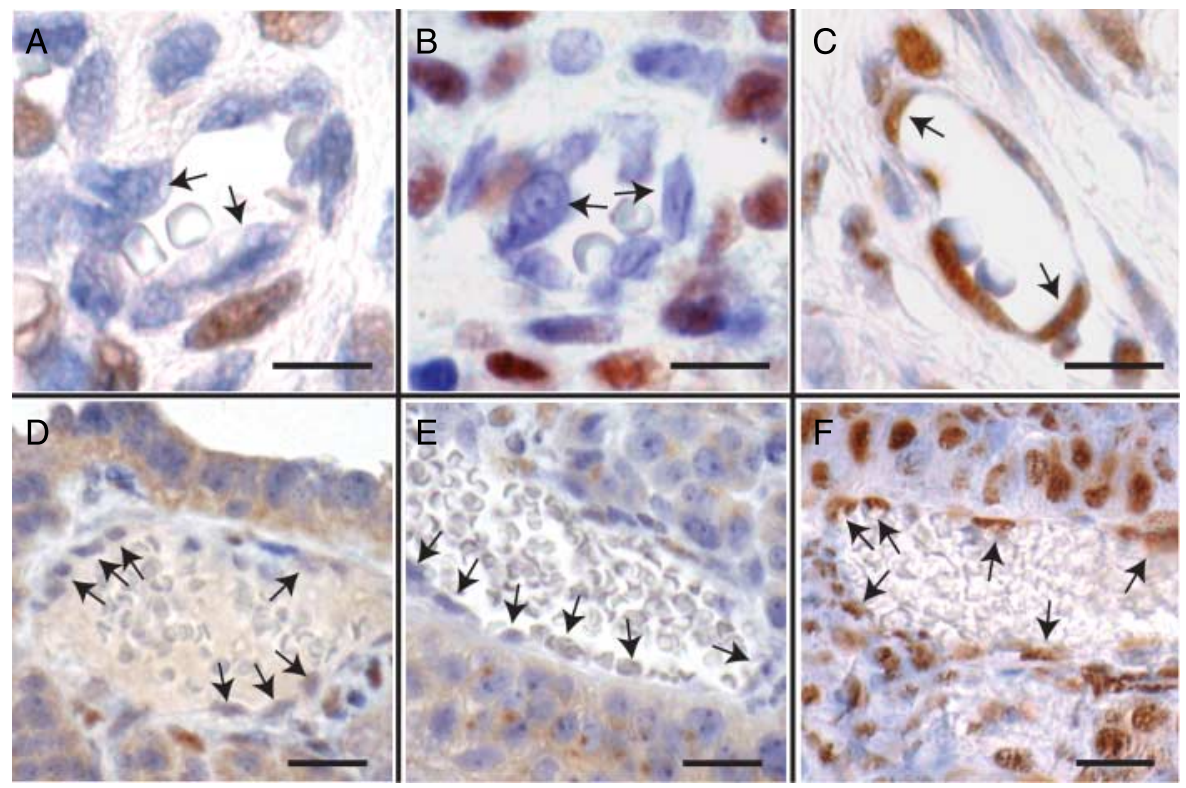

Figure 8 Areas of stroma from marmosets showing localisation of (A and D) PR, ( $B$ and $E$ ) $E R \alpha$ and ( $C$ and $F$ ) $E R \beta$ in early secretory phase endometrium of blood vessels (top panel) and in large maternal vessels at week 3 of pregnancy. Note the absence of $P R$ and $E R \alpha$ from the endothelial cells (arrows) (E) lining the blood vessels which are strongly stained for ER $\beta$ Top panel, scale bar $=100 \mu \mathrm{m}$; bottom panel, scale bar $=20 \mu \mathrm{m}$.

(Einspanier et al. 2006a) and novel embryonic stem cell lines have been derived from this species (Sasaki et al. 2005) taking advantage of the benefits of the special features of its reproductive cycle.

\section{Acknowledgements}

We thank Prof. Hilary O D Critchley and Prof. Philippa T K Saunders for valuable discussions, Helen Wilson for expert assistance, Ian Swanston for assays, Keith Morris for collection of tissue, Ted Pinner for graphics and Dr S J Wiegand and Dr J S Rudge (Regeneron Pharmaceuticals, Tarrytown, NY, USA) for the gift of VEGF Trap. The authors declare that there is no conflict of interest that would prejudice the impartiality of this scientific work.

\section{References}

Abbott DH, Barnett DK, Colman RJ, Yamamoto ME \& SchultzDarken NJ 2003 Aspects of common marmoset basic biology and life history important for biomedical research. Comparative Medicine 53 339-350.

Albrecht ED \& Pepe GJ 2003 Steroid hormone regulation of angiogenesis in the primate endometrium. Frontiers in Bioscience 8 416-429.

Brenner RM \& Slayden OD 1994 Cyclic Changes in the Primate Oviduct and Endometrium. In Physiology of Reproduction, pp 541569. Eds E Knobil \& JD Neill. New York: Raven Press.

Brenner RM \& Slayden OD 2004 Steroid receptors in blood vessels of the rhesus macaque endometrium: a review. Archives of Histology and Cytology 67 411-416.

Carroll RI, Mah K, Fanton JW, Magginis GN, Brenner RM \& Slayden OD 2007 Assessment of menstruation in the vervet (Cercopithecus aethiops). American Journal of Primatology 69 1-16.

Critchley HO, Brenner RM, Henderson TA, Williams K, Nayak NR, Slayden OD, Millar MR \& Saunders PT 2001 Estrogen receptor $\beta$, but not estrogen receptor $\alpha$, is present in the vascular endothelium of the human and nonhuman primate endometrium. Journal of Clinical Endocrinology and Metabolism 86 1370-1378.

Critchley HO, Kelly RW, Brenner RM \& Baird DT 2003 Antiprogestins as a model for progesterone withdrawal. Steroids 68 1061-1068.

Dickson SE \& Fraser HM 2000 Inhibition of early luteal angiogenesis by gonadotropin-releasing hormone antagonist treatment in the primate. Journal of Clinical Endocrinology and Metabolism 85 2339-2344.

Dunn CL, Kelly RW \& Critchley HO 2003 Decidualization of the human endometrial stromal cell: an enigmatic transformation. Reproductive Biomedicine Online 7 151-161.

Einspanier A, Lieder K, Bruns A, Husen B, Thole H \& Simon C 2006 a Induction of endometriosis in the marmoset monkey (Callithrix jacchus). Molecular Human Reproduction 12 291-299.

Einspanier A, Lieder K, Einspanier R \& Husen B 2006b The common marmoset monkey as a model for implantation and early pregnancy research. Methods in Molecular Medicine 121 111-121.

Enders AC 2000 Trophoblast-uterine interactions in the first days of implantation: models for the study of implantation events in the human. Seminars in Reproductive Medicine 18 255-263.

Ferrara N 2004 Vascular endothelial growth factor: basic science and clinical progress. Endocrine Reviews 25 581-611.

Fraser HM \& Lunn SF 1999 Non human primates in female reproductive medicine. In Reproduction in Nonhuman Primates: a Model System for Human Reproductive Physiology and Toxicology, pp 27-59. Eds GF Weinbauer \& R Korte. Munster, New York: Waxmann Verlag.

Gilchrist RB, Wicherek M, Heistermann M, Naydu PL \& Hodges JK 2001 Changes in follicle stimulating hormone and follicle populations during the ovarian cycle of the common marmoset. Biology of Reproduction 64 127-135.

Harlow CR, Gems S, Hearn JP \& Hodges JK 1983 The relationship between plasma progesterone and the timing of ovulation and early embryonic development in the marmoset monkey (Callithrix jacchus). Journal of Zoology 201 273-282.

Harlow CR, Hearn JP \& Hodges JK 1984 Ovulation in the marmoset monkey: endocrinology, predication and detection. Journal of Endocrinology 103 17-24.

Harris HA 2007 Estrogen receptor- $\beta$ : recent lessons from in vivo studies. Molecular Endocrinology 21 1-13. 
Henderson TA, Saunders PT, Moffett-King A, Groome NP \& Critchley HOD 2003 Steroid receptor expression in uterine natural killer cells. Journal of Clinical Endocrinology and Metabolism $\mathbf{8 8}$ 440-449.

Hild-Petito S, Verhage HG \& Fazleabas AT 1992 Immunocytochemical localization of estrogen and progestin receptors in the baboon (Papio anubis) uterus during implantation and pregnancy. Endocrinology $1302343-2353$.

Holash J, Davis S, Papadopoulos N, Croll SD, Ho L, Russell M, Boland $P$, Leidich $R$, Hylton D, Burova $E$, loffe $E$, Huang $T$, Radziejewski C, Bailey K, Fandl JP, Daly T, Wiegand SJ, Yancopoulos GD \& Rudge JS 2002 VEGF-TrRudgerap: a VEGF blocker with potent antitumor effects. PNAS 99 11393-11398.

Hubler TR, Denny WR, Valentine DL, Cheung-Flynn J, Smith DF \& Scammell JG 2003 The FK506-binding immunophilin FKBP51 is transcriptionally regulated by progestin and attenuates progestin responsiveness. Endocrinology 144 2380-2387.

Jabbour HN, Kelly RW, Fraser HM \& Critchley HOD 2006 Endocrine regulation of menstruation. Endocrine Reviews 27 17-46.

Kholkute SD, Nandedkar TD \& Puri CP 2000 Localization of estrogen and progesterone receptors in the endometrium of common marmosets Callithrix jacchus. Indian Journal of Experimental Biology 38 425-431.

Krikun G, Schatz F, Taylor R, Critchley HO, Rogers PA, Huang J \& Lockwood CJ 2005 Endometrial endothelial cell steroid receptor expression and steroid effects on gene expression. Journal of Clinical Endocrinology and Metabolism 90 1812-1818.

Lecce G, Meduri G, Ancelin M, Bergeron C \& Perrot-Applanat M 2001 Presence of estrogen receptor $\beta$ in the human endometrium through the cycle: expression in glandular, stromal, and vascular cells. Journal of Clinical Endocrinology and Metabolism 86 1379-1386.

McKinnell C, Saunders PT, Fraser HM, Kelnar CJ, Kivlin C, Morris KD \& Sharpe RM 2001 Comparison of androgen receptor and oestrogen receptor $\beta$ immunoexpression in the testes of the common marmoset (Callithrix jacchus) from birth to adulthood: low androgen receptor immunoexpression in Sertoli cells during the neonatal increase in testosterone concentrations. Reproduction 122 419-429.

Milne SA, Henderson TA, Kelly RW, Saunders PT, Baird DT \& Critchley HOD 2005 Leukocyte populations and steroid receptor expression in human first-trimester decidua; regulation by antiprogestin and prostaglandin E anlalog. Journal of Clinical Endocrinology and Metabolism 90 4315-4321.

Murray MJ, Zhang J \& Lessay BA 1999 Expression of $\alpha 6$ and $\beta 4$ integrin subunits throughout the menstrual cycle: no correlation with uterine receptivity. Fertility and Sterility 72 522-526.

Narkar M, Kholkute S, Chitlange S \& Nandedkar T 2006 Expression of steroid hormone receptors, proliferation and apoptotic markers in primate endometrium. Molecular and Cellular Endocrinology 246 107-113.

Nayak NR \& Brenner RM 2002 Vascular proliferation and vascular endothelial growth factor expression in rhesus macaque endometrium. Journal of Clinical Endocrinology and Metabolism 87 1845-1855.

Niklaus AL, Murphy CR \& Lopata A 2001 Characteristics of the uterine luminal surface epithelium at preovulatory and preimplantation stages in the marmoset monkey. Anatomical Records 264 82-92.

Rowe AJ, Morris KD, Bicknell R \& Fraser HM 2002 Angiogenesis in the corpus luteum of early pregnancy in the marmoset and the effects of vascular endothelial growth factor immunoneutralization on establishment of pregnancy. Biology of Reproduction 67 1180-1188.

Rowe AJ, Wulff C \& Fraser HM 2003 Localisation of mRNA for vascular endothelial growth factor (VEGF), angiopoietins and their receptors during the peri-implantation period and early pregnancy in marmosets (Callithrix jacchus). Reproduction 126 227-238.
Rowe AJ, Wulff C \& Fraser HM 2004 Angiogenesis and microvascular development in the marmoset (Callithrix jacchus) endometrium during early pregnancy. Reproduction 128 107-116.

Rune GM, Leuchtenberg U, Schroterkermani C \& Merker HJ 1992 Zonal differentiation of the marmoset (Callithrix-jacchus) endometrium. Journal of Anatomy 181 301-312.

Sasaki E, Hanazawa K, Kurita R, Akatsuka A, Yoshizaki T, Ishii $\mathbf{H}_{\text {, }}$ Tanioka Y, Ohnishi Y, Suemizu H, Sugawara A, Tamaoki N, Izawa K, Nakazaki Y, Hamada H, Suemori H, Asano S, Nakatsuji N, Okano H \& Tani K 2005 Establishment of novel embryonic stem cell lines derived from the common marmoset (Callithrix jacchus). Stem Cells 23 1304-1313.

Saunders PTK, Millar MR, Williams I, MacPherson S, Harkis D, Anderson RA, Orr B, Groome NP, Scobie G \& Fraser HM 2000 Differential expression of estrogen receptor- $\alpha$ and $-\beta$ and androgen receptor in the ovaries of marmosets and humans. Biology of Reproduction 63 1098-1105.

Sierens JE, Scobie GA, Wilson J \& Saunders PT 2004 Cloning of oestrogen receptor $\beta$ from old and new world primates: identification of splice variants and functional analysis. Journal of Molecular Endocrinology 32 703-718.

Smith KB \& Fraser HM 1991 Control of progesterone and inhibin secretion during the luteal phase in the macaque. Journal of Endocrinology 128 107-113.

Snijders MP, de Goeij AF, Debets-Te Baerts MJ, Rousch MJ, Koudstaal J \& Bosman FT 1992 Immunocytochemical analysisi of oestrogen and progesterone receptors in the human uterus throughout themesutrual cycle and after the menopause. Journal of Reproduction and Fertility 94 363-371.

Summers PM, Wennink J \& Hodges JK 1985 Cloprostenol-induced luteolysis in the marmoset monkey (Callithrix jacchus). Journal of Reproduction and Fertility 73 133-138.

Taylor PD, Hillier SG \& Fraser HM 2004 Effects of GnRH antagonist treatment on follicular development and angiogenesis in the primate ovary. Journal of Endocrinology 187 1-17.

Taylor PD, Hillier SG, Wiegand SJ \& Fraser HM 2006 Dissociation of vascular endothelial growth factor-regulated angiogenesis and expansion of the primate preovulatory follicle. Endocrinology Submitted.

Westberry JM, Sadosky PW, Hubler TR, Gross KL \& Scammell JG 2006 Glucocorticoid resistance in squirrel monkeys results from a combination of a transcriptionally incompetent glucocorticoid receptor and overexpression of the glucocorticoid receptor co-chaperone FKBP51. Journal of Steroid Biochemistry and Molecular Biology 100 34-41.

Wulff C, Wilson H, Rudge JS, Wiegand SJ, Lunn SF \& Fraser HM 2001 Luteal angiogenesis: prevention and intervention by treatment with vascular endothelial growth factor trap A40. Journal of Clinical Endocrinology and Metabolism 86 3377-3386.

Wulff C, Wilson H, Wiegand SJ, Rudge JS \& Fraser HM 2002 Prevention of thecal angiogenesis, antral follicular growth, and ovulation in the primate by treatment with vascular endothelial growth factor trap R1R2. Endocrinology 143 2797-2807.

Wulff C, Weigand M, Kreienberg R \& Fraser HM 2003 Angiogenesis during primate placentation in health and disease. Reproduction 126 569-577.

Received 12 October 2006

First decision 2 November 2006

Revised manuscript received 2 April 2007

Accepted 20 April 2007 